\title{
A maldição da memória
}

\section{Janaína de Azevedo Baladão*}

\begin{abstract}
Resumo: Este trabalho se propõe a analisar a construção e a formação da memória do narradorpersonagem de Assim na Terra de Luiz Sérgio Metz (1995). Em sua trajetória, esse narrador-personagem percorre uma multiplicidade de memórias, revivendo e recombinando experiências. Assim, imerso em muitas rememorações, discute a construção narrativa, a criação de personagem e a recepção do leitor.
\end{abstract}

Palavras-chave: Memória; Luiz Sérgio Metz; Assim na Terra.

\begin{abstract}
This paper proposes the analysis of the character-narrator's construction and formation of memory in Assim na Terra by Luiz Sérgio Metz (1995). During his trajectory, this character-narrator goes through a multiplicity of memories, reliving and recombining his experiences. Thus, immersed in many of these reminiscences, he discusses the narrative's construction, the character's creation and the reader's reception.
\end{abstract}

Keywords: Memory; Luiz Sérgio Metz; Assim na Terra.

Assim na Terra, ${ }^{1}$ de Luiz Sérgio Metz, ${ }^{2}$ está assim na memória. Um homem não apenas caminha, escreve e se descobre. Recolhe-se e discorre sobre o processo da construção do personagem, do autor-leitor-obra, traduzindo e decodificando o que sua memória lhe fornece: fatos que viveu, recordações esparsas, episódios que viu, coisas que imaginou, sentimentos, sensações, leituras, interpretações, acontecimentos esquecidos. É a soma do que viveu, do que suportou. É a linguagem de seus avós, a tradição, a voz dos autores que leu, é a internalização de vários conhecimentos para se produzir uma obra: "Eu apago, eu escrevo, eu sinto. Eu translitero, e minha imagem esfarrapada une, eu junto o lábio no outro e os escuto" (METZ, 1995, p.53).

\section{Formulação do enredo}

\footnotetext{
* Tradutora, mestranda em Literaturas de Língua Espanhola na Universidade Federal do Rio Grande do Sul. Bolsista CAPES. E-mail: janabaladao@uol.com.br.

${ }^{1}$ METZ, Luiz Sérgio. Assim na Terra. Porto Alegre: Artes \& Ofícios, 1995.

${ }^{2}$ O escritor e jornalista Luiz Sérgio "Jacaré" Metz nasceu em Santo Ângelo, em 1952. Publicou o livro de contos O primeiro e o segundo homem (1981); a biografia sobre Aureliano de Figueiredo Pinto, pertencente à coleção Esses Gaúchos (1986); e o romance Assim na Terra (1995), ganhador do Prêmio Açorianos de Literatura. Faleceu em 20 de junho de 1996. Terra adentro (2006) é uma publicação póstuma, realizada em conjunto com Pedro Luís Osório e Tau Golin. Nesse livro, registra-se a passagem desses três amigos pelo vasto cenário pampeano.
} 
O enredo de Assim na Terra (1995) não apresenta limites precisos. Inicialmente, está dividido em pequenos capítulos que se referem às estações do ano, marcando também um ciclo em desenvolvimento entre a infância (primavera), a adolescência (verão), a maturidade (outono) e o declínio (inverno) do personagem, que também deverá ser seu próprio recomeço. Nessa narrativa breve, estabelecem-se referências líricas à primavera, que começa em setembro, "mês estético, alerta, delgado" (METZ, 1995, p.7), quando "não há nenhum sistema, os símbolos estão se conhecendo" (METZ, 1995, p.8); ao verão, quando “os vocábulos estavam submetidos a um pulso a um movimento de coisas rentes aos corpos ensopados e cabelos úmidos: não se mexe uma folha" (METZ, 1995, p.10); ao outono, que manifesta "o mio de uma lembrança de uma outra chuva" de um tempo distante (METZ, 1995, p.12); e ao inverno, período no qual as "pessoas sós fazem o fogo para imaginar sua gente que em algum canto do sul está repetindo em contraponto o estalo da lenha e nos nós dos dedos, com as fisionomias que se guardam nesses álbuns da memória dos invernos" (METZ, 1995, p.13). O frio do inverno é o clima propício para introduzir os próximos três capítulos do livro que se seguem, pois "a fala e o século se assemelham e o clima determina o diálogo, e é dito que no sul: Tá de renguear, Gomercindo” (METZ, 1995, p.14).

No capítulo I, o narrador-personagem (que durante toda a narrativa não revelará seu nome) apresenta-se dizendo que veio "desses fogos, dessas almas, do negaceio brilhante do sol caindo no fundo da fenda da coxilha" (METZ, 1995, p.15), em uma cidade em mudança: "cidade rejuntada pelas últimas tropas bravias", onde "boi e tropeiro, colorados de pó, se foram" (METZ, 1995, p.15). Nesse mundo novo, entre esquecimento e lembrança, vai reconstruindo sua infância: amigos, "esboços de unidades" (METZ, 1995, p.16), pessoas, fantasmas, o "alarido que vem do mundo adulto" (METZ, 1995, p.18). Inicia-se, então, uma caminhada: "tudo estava andando dentro dos sinais. Deveria interpretá-los, revolver pegadas, achar [seu] próprio caminho" (METZ, 1995, p.21). Como Saint-Hilaire em suas expedições, faz anotações, classifica e cataloga em uma caderneta de notas que carregava no bolso das calças. Para começar a escrever, registra "instantes desintegrados” (METZ, 1995, p.20), oriundos de um tremor de imagens, ${ }^{3}$ buscando "a vértebra do verbo, o verbo por dentro e por fora" (METZ, 1995, p.21). Esses fragmentos vêm do que abarca sua memória e "a memória estava em todos os lugares" (METZ, 1995, p.27).

\footnotetext{
${ }^{3}$ Para Julio Cortázar, em "Algunos aspectos sobre el cuento" (2004), somente com imagens se pode transmitir a alquimia secreta que explica a profunda ressonância que uma grande história tem em nós, é como um tremor de água dentro de um cristal, uma fugacidade em uma permanência.
} 
Ao chegar a uma encruzilhada, presencia a cena de um homem, descendente dos linguarás, que vendia a alma ao demônio. Diante de um formigueiro, em um estranho ritual, esse desconhecido pede ajuda a Tatanho. Enquanto murmura o pedido, uma centena de formigas toma seu corpo à ferroada. Impassível, o homem fica à espera, santificando-se. $\mathrm{O}$ narrador-personagem, depois de assistir à cena, caminha até o formigueiro e imagina o que poderia pedir em troca, caso colocasse também suas mãos ali. Não sabe ao certo: "Mas se conseguisse escrever, na intercessão, uma parábola missioneira genuína e geral como melodia que toca o boi e o amor com simultânea embriaguez?" (METZ, 1995, p.26).

Entre sonhos e pesadelos relembra a infância, as cenas da mãe, porém as máquinas e o mundo real o tiram dessa contemplação. Para começar a escrever sabe que "tem uma infinidade de pequenos começos" (METZ, 1995, p.30), "assuntos que ainda não são comuns" (1995, p.31); no entanto, antes de escolher as palavras, nada tem significado, tudo é "silêncio, bruma, vazio" (METZ, 1995, p.47). Nesse dilema, encontra Gomercindo, um homem ao redor dos 70 anos, que dormia profundamente. Trajava bombachas, casaco de lã e botas embarradas e em seu cinto podia-se ler as iniciais GS. Juntos, caminharam enveredando por uma trilha.

No capítulo II, em um cenário pampeano, empreendem uma viagem: “Gomercindo ao lado, o olhar longe e perto, no que cai, move, se esconde" (METZ, 1995, p.51). Nesse percurso, o narrador-personagem mostra sinais de cansaço: "o sono estava no fundo erradio da memória, ele sim caçando. Dali enviando aquelas coisas: imaginação, intuição, realidade aparente" (METZ, 1995, p.52). Refere-se a novas e antigas experiências, busca novas percepções e percebe as "portas abertas" para o início de uma escritura (METZ, 1995, p.57). Apesar de fatigado, em um lugar que denomina de galpão, sente-se pronto para começar "um trabalho sobre o sul" (METZ, 1995, p.57) e, entre angústia e ansiedade, diante do vazio, Gomercindo surge como "algo luminoso" (METZ, 1995, p.59). Sentado diante de uma escrivaninha, envolto nesse processo de escrita, o narrador-personagem percebe que está emagrecendo rapidamente. Estabelece uma conversa com Gomercindo, que o manda escrever logo, pois a maior parte da vida é esquecida: “A palavra é de outra esfera, entre a saudade e a ação" (METZ, 1995, p.68).

Gomercindo tem na memória o conhecimento de seus antepassados, mas afirma que é outra pessoa, com outros pensamentos, pois cada vez que se pensa ou se escreve algo, já é de modo diferente do que originalmente foi dito ou escrito. Gomercindo, peça-chave do enredo, cria um ambiente que chama de "Pensário", onde guarda a matéria e a memória do tempo. É então que conta sua história: tentou levar adiante uma oficina para consertos, mas não tinha 
habilidade, pois "estragava o estrago" (METZ, 1995, p.71). Trabalhou na terra até adoecer e ser internado em um hospital. O trabalho feito nas terras ficou arruinado e Gomercindo foi interditado, perdeu bens e herança, mas não apreenderam seu conhecimento sobre a vida, sobre o que sabia em relação ao inverno (METZ, 1995, p.71). Havia sido professor de crianças "até que seus pais não mais as suportaram" (METZ, 1995, p.71), ficou só, viajou, entrou para o contrabando, conheceu melhor a fronteira, comprou e leu muitos livros castelhanos. Tornou-se indispensável para seu grupo, ganhou muitas lutas, perdeu outras tantas, amou e sofreu.

Enquanto Gomercindo rememorava, o narrador-personagem tentava reconhecer a figura dele entre as pessoas de sua família e entre as outras pessoas que conheceu na vida. Gomercindo ia se apropriando das palavras do narrador-personagem. Em transe, o narradorpersonagem começa a escrever conforme dita Gomercindo. Em êxtase, febril, escuta vozes, procura por palavras, emagrece um pouco mais. Gomercindo traz pão de linho e coalhada e, sobre o travesseiro, deixa algumas anotações: "Era um relato estranho, telegráfico e cerebral, sem unidade.” (METZ, 1995, p.82). Lentamente, o narrador-personagem encontra um caminho, "dentro do Pensário, apenas a luz de uma janela quase aberta" (METZ, 1995, p.93), e entre todas as artes possíveis, escolhe a literatura, "narrar num papel o que fora e não fora escrito" (METZ, 1995, p.94). De antemão, pondera: “Tudo o que agora Gomercindo havia feito, segundo ele, fora somar e relacionar, mas não de maneira a tornar um no outro, transfundido. Havia feito um texto estanque" (METZ, 1995, p.94). Os dias passam de forma lucilante até que o narrador-personagem sai do Pensário.

No capítulo III, o cenário é aberto, erguem-se a querência, os campos remetem às palavras:

Palavras que estão onde as pás não mais as alcançam e que fazem vus no olhar dos potros e somem para dentro dos bambás de um ou outro povo de idêntica dor, de som de palma, de palma de mão, de palmas em círculo, de ciranda e de saudade. (METZ, 1995, p.105).

Nesse mundo, onde o homem e seu cavalo se confundem, o narrador-personagem escolhe a noite e o silêncio como eito do caminho, pois o que o poeta "faz e escreve pertence ao silêncio de cada um" (METZ, 1995, p.112). Em meio à caminhada, Gomercindo e o narrador-personagem trocam o chapéu ritualisticamente, como forma de amizade e confiança, apesar de nunca terem falado "na palavra pacto" (METZ, 1995, p.113).

Nas palavras de Gomercindo, o ser humano não se compreende e não compreende o outro: "Inventamos uma invenção que nos inventa, ficamos alguns instantes felizes com isso" (METZ, 1995, p.114). Nessa invenção, é possível criar vidas e mundos falsos para suportar a 
vida. "Se criarmos diferentes pistas de memória, não estaremos presos a um único tempo, nem a tanta idade, nem a uma única memória básica" (METZ, 1995, p.114), mas nossa infância, nosso passado nos contagia e nos propõe um eterno retorno. Em um tempo distante, não havia pressa: "A terra terminava bem perto, e assim na terra logo começava o céu" (METZ, 1995, p.116). O narrador-personagem segue anotando em sua caderneta, nessa viagem que não era para confrontar, "mas para defrontar, segundo Gomercindo, o dentro e o fora" (METZ, 1995, p.118). Porém, necessitava de mais gente a seu lado para iniciar "uma hermenêutica do sul, com calma acadêmica e o vigor dos demônios" (METZ, 1995, p.118).

Várias imagens surgem, então: sombras, cavernas, galhos, vegetação cerrada, paradeiros, que irão retardar ou acelerar a cavalgada. O narrador-personagem não consegue mais dialogar, sente-se angustiado, perde as frases, em uma "sensação de secura, retenção desarvoramento" (METZ, 1995, p.132) e pergunta-se perplexo: “Como escrever capítulos quando não há mais possibilidade de um todo? Qual rosto tem os seres que perambulam ao largo dos nossos cavalos se já não são visíveis nem mesmo concebíveis? Onde estão os fragmentos desse enredo estilhaçado, sem sujeito, sem objeto, mas cada vez mais vivo, mais real, mais estranho?” (METZ, 1995, p.133). Nessa inquietação, talvez nada fosse real, nem mesmo Gomercindo. De fato, a partir desse ponto, os dois vendariam os olhos e seguiriam cegamente, abandonando "o mundo das preocupações" (METZ, 1995, p.141). Essa é a última imagem que o narrador-personagem retém de Gomercindo, pois, segundo suas crenças, o que perdura é o que se pode guardar dentro de si, ou seja, o que pode ser plasmado na memória.

Gomercindo lembra-se de uma mulher e é essa a imagem que se forma na imaginação do narrador-personagem, a imagem que permanece viva. Essa mulher seria o sujeito, o objeto do retrato, aquela que surge quando esquecida, digna de tornar-se um tema literário. As frases entre eles, depois dessa revelação, caíram "no silêncio ou no sono" (METZ, 1995, p.144), até que o narrador-personagem esbarra no corpo caído de Gomercindo: "Ouvia-se mesmo umas páginas levitando, [...] não secas, não verdes, não muitas” (METZ, 1995, p.145). As imagens caíam em bloco sob o narrador-personagem, "como se estivesse sendo sacudido e voltasse há algum tempo" (METZ, 1995, p.145). "O pacto fora cumprido" (METZ, 1995, p.145), os dois estão inexoravelmente juntos, mas tudo "passa, tudo cala, tudo é vento sobre a noite. [...] O tempo e o homem se excluem na mesma luz" (METZ, 1995, p.147).

Nesse ponto do relato, a narrativa retoma as estações. Assim na Terra (1995), como já mencionado, inicia com a seguinte ordem: Primavera, Verão, Outono e Inverno. A partir daí, seguem-se três capítulos, denominados I, II e II, finalizando com as estações Inverno, 
Primavera, Verão e Outono. Ao capítulo Inverno da primeira parte, após intervalo entre os capítulos I, II e III, soma-se mais uma vez outro capítulo Inverno, quando, em recolhimento, o narrador-personagem diz: "Para ler a memória do velho basta compará-lo com a memória de outros invernos anteriores, chegando à infância da linhagem, no ar, na água, na ruga. Intempérie, zelo, encordoar. Começo e fim sob a boina de esquilador no inverno" (METZ, 1995, p.150). Em seguida, na Primavera, no "sul [o narrador-personagem pescou] à margem de um rio, e dava bem para lê-lo. Um texto claro, prateado, também dourado" (METZ, 1995, p.151). No Verão, descobriu muitas palavras novas e em um "entardecer garoou. O que restava de terra sobre as pedras penetrou no ralo das pedras. A lua bateu sobre elas, de comprido, e as fez rebrilhar. Era a túnica da terra. A terra abotoada" (METZ, 1995, p.153). No Outono, amadurecido, evocou um "panorama várias vezes riscado, escrito sem calma, estampido quase, mesmo em sua memória" (METZ, 1995, p.155), afirmando que "um lugar é habitado e habitável quando dele se pode ter saudade, sempre e somente saudade" (METZ, 1995, p.156).

\section{A maldição pela memória: o eterno retorno}

- Fiz isto - diz-me a memória. Não posso ter feito - sustenta meu orgulho, que é inexorável. Finalmente o que cede é a memória. (NIETZSCHE apud ABBAGNANO, 1999, p.659)

Essa volta ao começo marca o caráter cíclico, o mito do eterno retorno da narrativa: "no começo o fim, no fim o começo. ${ }^{4}$ A maldição pela memória” (METZ, 1995, p.49). Se pensarmos na primeira ordem Primavera-Verão-Outono-Inverno e na segunda InvernoPrimavera-Verão-Outono, teremos novamente o Inverno como centro (tanto no que se refere à intersecção, quanto à seqüência final que desembocaria novamente em um novo Inverno). O acesso a esse tempo de meditação e de busca de entendimento se dá por meio da memória, que representa a possibilidade de evocar os acontecimentos passados. Esses acontecimentos passados já estiveram disponíveis de alguma forma e repetidamente surgem diante do

\footnotetext{
${ }^{4}$ T. S. Eliot, no primeiro verso de "East Coker", de Os quatro quartetos (apud KENNER, 1974, p.263), diz: "In my beginning is my end", ou seja, "No meu começo o meu fim". Nesse sentido, vale a pena reler os versos de "Little Gidding", de Os quatro quartetos (ELIOT, 1967, p.61): “O que chamamos princípio é quase sempre o fim/E alcançar um fim é alcançar um princípio./Fim é o lugar e onde partimos. E cada frase/Ou sentença de rigor (onde cada palavra se ajusta,/Assumindo seu posto para suportar as demais,/A palavra sem pompa ou timidez,/Um natural intercâmbio do antigo e do novo,/A palavra de cada dia, correta e sem vulgaridade,/A palavra exata e formal, mas não pedante,/O completo consórcio de um bailado simultâneo)/Cada frase e cada sentença são um fim e um princípio,/Cada poema é um epitáfio. E qualquer ação/É um passo rumo ao todo, ao fogo, uma descida à garganta do mar.
} 
narrador-personagem. Para Jorge Luis Borges, em "Everness".: "Sólo una cosa no hay. Es el olvido. Dios que salva el metal salva la escoria y cifra en Su profética memoria las lunas que serán y las que han sido".

Em Questões sobre memória Iván Izquierdo (2004, p.57) aclara: “É possível extinguir ou reprimir memórias de maneira tão intensa que estas, na prática, desaparecem do repertório habitual, como se de fato estivessem esquecidas. Mas não estão; sempre há maneiras de trazêlas novamente à tona". Sabedor de que a memória é capaz de pregar peças tais como o esquecimento ou o apagamento de fatos importantes, o narrador-personagem toma notas. Quando percebe um fato ao qual atribui um significado importante pontua: "Deveria anotar aquela escrita passageira de dois passantes que se observam, avisos, recados rápidos, ardentes, feridos que ficam pelo esquecimento" (METZ, 1995, p.20).

Em um primeiro momento, o narrador-personagem entra em um tempo de recolhimento e de recordação para buscar um tema para o livro, ou seja, para iniciar precisa encontrar um objetivo, uma idéia que trame o fio narrativo e nesse fim, ou melhor, nessa finalidade é que está o começo. O primeiro passo a seguir é encontrar o objetivo, o ponto de partida, juntar, descobrir a palavra certa, inovar e conseguir escrever na folha em branco. Nessa procura, paralelamente, o narrador-personagem vai estabelecendo um questionamento sobre o que é e como funciona a memória, o que é imaginação, como e o quê escrever: “Tempo mesmo é esquecimento, a duração do esquecimento não é tempo, lembrança não é tempo, recordação não é memória. No meu fim o meu começo" (METZ, 1995, p.84). Diante de múltiplas possibilidades, diz:

\footnotetext{
Uma infinidade de pequenos começos enxameavam minha cabeça cheia de assuntos. [...] Pensei que assim as coisas entram na gente, sem querer elas faziam parte de mim agora. Nunca as imaginei, nunca as procurei e no entanto elas se misturavam entre os nascimentos da memória e para sempre estavam ali, amarelas, e sequer estranhas, sequer dissonantes no povoar de imagens. Associavam-se e auto-evocavam-se, parecia que fora ontem. Transitavam livremente entre xergões e estrelas. Pensei em rejeitá-las, expulsá-las de mim enquanto era tempo. Mas o que passa pela cabeça, não passa. (METZ, 1995, p.30-31)
}

Segundo IZQUIERDO (2004, p.21), as memórias "provêm ou das experiências ou de insights. Há tantas memórias possíveis como há experiências e insights possíveis; ou seja, muitíssimas; um número indefinido porém finito, já que nossa vida é finita”. Então, entre as primeiras peças que entram em contato com o cavalo (os xergões) e as estrelas há infinitas possibilidades de recordações, que estão intrinsecamente ligadas às experiências, à percepção,

\footnotetext{
${ }^{5}$ BORGES, Jorge Luis. Obra poética, 2. Madrid: Alianza, 1998.
} 
à imaginação, à recombinação de memórias e aos insights do narrador-personagem. A evocação do registro das imagens dessas experiências ou dessas percepções vai produzir a materialização de pensamentos e sentimentos que sempre estiveram presentes, que se tornaram agentes no plano extremo da consciência do narrador-personagem. A grande caminhada do narrador-personagem, nesse sentido, é dentro de si, por um caminho interior "onde não havia brita, onde não havia asfalto", onde a memória se acende e se perpetua eternamente:

Só ela linda, a noite daqueles dias sem estações balançava sobre as torres. Saí do colégio e fui andando, fui deixando, fui passando. Súbito olhei para trás. Tudo ficará lá, imóvel, impenetrável, dançando nas asas dos galos de lata dos telhados rangentes. Os fogões, as mãos que tocam a cinza e os olhos que a reviram, a memória que isso acende, isso ficou. Pensei em todos eles que me transpassaram cada momento e que sonharam por mim e fui andando. Fui andando onde não havia brita, onde não havia asfalto, por onde a terra era terra, pela fala da água e pela fala da pedra, pela lágrima, pelo tempo presente vazado na camiseta. (METZ, 1995, p.19) [grifo nosso]

\title{
3 A arca da memória
}

\begin{abstract}
Ah, mas falo falso. O senhor sente? Desmente? Eu desminto. Contar é muito, muito dificultoso. Não pelos anos que se já passaram. Mas pela astúcia que têm certas coisas passadas - de fazer balancê, de se remexerem dos lugares. O que eu falei foi exato? Foi. Mas teria sido? Agora, acho que nem não. São tantas horas de pessoas, tantas coisas em tantos tempos, tudo miúdo recruzado. (ROSA, 1988, p.159)
\end{abstract}

Alcuíno no tratado De rethorica diz: "A memória é a arca de todas as coisas e se ela não se tornou a guardiã do que se pensou sobre coisas e palavras, sabemos que todos os outros dotes do orador, por mais excelentes que possam ser, se reduzem a nada" (ALCUÍNO apud LE GOFF, 2006, p.447). Em uma linguagem densa, repleta de metáforas relacionadas à natureza e ao cotidiano, o narrador-personagem aponta o caminho para o nascimento de um texto, reproduzindo um mundo antigo e um mundo em evolução e revelando relações e migrações culturais de cunho oral oriundas de muitas gerações de "brancos, negros e índios" (METZ, 1995, p.151) com suas maneiras de contar causos em "vozes que [o] antecederam ou sucederam. Algumas delas, no passado e no futuro, dos que procuram a mesma coisa. Alguns que edificaram, com prumo e pedra um sentimento. Vozes que se fundem sob a sombra e sob o frio [...]" (METZ, 1995, p.81). "Mas há momentos em que a própria natureza recua, desaparece" (METZ, 1995, p.78), então, o narrador-personagem se vale de artifícios mnemônicos e memoriza, por exemplo, os sons dos pássaros para mantê-los sempre presentes. 
O narrador-personagem mostra essa atitude elementar e instintiva, muitas vezes acompanhada de crenças de origem remota ligadas aos ciclos da natureza, ao narrar, por exemplo, a leitura dos esquiladores conhecedores dos meandros do inverno, que podem ler “com a ajuda do sol na onda dos fios os mínimos anéis de sinais de vida levada desde a última tosa” (METZ, 1995, p.149). Nessa evocação de um mundo anterior, com suas lendas e misticismos, exatamente quando a "terra terminava bem perto" (METZ, 1995, p.116), como já vimos antes, o narrador-personagem põe em evidência seu conhecimento e sua experiência, reinterpretando fatos passados. Reconta, por exemplo, o que escutou sobre o texto e sobre o tempo: "Ouvi um mendigo dizer para o outro: isso é vender laranja para o ferro velho. Isso é doação, textualidade de um para o outro, viva necessária. Texto talvez seja tempo de alguém. Se for, é tempo vindo de outro tempo. Um choque de tempo: laranja e ferro" (METZ, 1995, p.85).

A arca de onde parte é a entrada da imaginação, do mundo consciente versus o que está guardado inconscientemente na memória do narrador-personagem. LE GOFF em História e Memória (2006, p.469) afirma que: “A memória é um elemento essencial do que se costuma chamar de identidade, individual ou coletiva, cuja busca é uma das atividades fundamentais dos indivíduos e das sociedades de hoje, na febre e na angústia”. Por esse viés, o narradorpersonagem, além de evocar imagens que já foram percebidas ou de realizar novas combinações de imagens, reflete a identidade coletiva, à medida que dispõe e traz à tona elementos históricos comuns, e também a identidade individual, já que revela experiências subjetivas únicas do narrador-personagem, que surgem sob estado de angústia e introspecção. Diz: "Eu procurava abri-la, e forçava sem muito ímpeto o tampo curvo. [...] Abri a arca e imaginei corsários rengos, bandeiras mortais. Lábios com espelhos e cobiça, feitiços, prismas retramados" (METZ, 1995, p.41).

Tal qual Mnemósine, deusa da memória, o narrador-personagem quanto mais reconta e narra seus feitos, fatos, sentimentos e impressões, ainda que dentro de um vasto campo de imagens emaranhadas, mais se preserva e se distancia do esquecimento:

Toquei um resto de parede, forcei um pouco, ela também desandou sobre umas coisas que foram assim novamente quebradas. [...] São esboços verdadeiros de uma edificação imemorial, instintiva, e consistem numa altaneiria de rejuntados esforços, mutirões secretos, fainais sigilosas, sem plantas num rabisco geométrico e fundam-se num formato de colares e linhas num determinado momento do espaço, parecendo bivaques esses núcleos habitacionais. Fragmentos recolhidos, depois pregados uns nos outros, uma na outra, cerrando os vazios, reforçando os lados onde o vento sopra. [...] Reciclos, rejuntes, coisas recolhidas lá e transportadas nas costas, fileiras de portas, bolsos cheios de pedaços de ferro. (METZ, 1995, p.43-44) [grifo nosso] 
Se, por um lado, ao reviver as recordações repetidamente o narrador-personagem aumenta a permanência da formação dessa memória, por outro, ao buscar recolher os fragmentos, corre o risco de falsificar, de misturar e recombinar experiências até o ponto de não estar mais seguro se o que lembra é verdadeiro ou não. Entretanto, essa tentativa de reconhecimento de imagens dispersas representa o ponto de partida para começar a escrever, pois sua "memória estava em todos os lugares, sentindo e [lhe] dizendo coisas em obscuros fundamentos e códigos de significados arredios e conjurados [...]” (METZ, 1995, p.27). Nesse processo de conhecimento, no meio dessa multiplicidade de memórias e de tantas lacunas, o narrador-personagem faz uma seleção para filtrar as experiências mais significativas. Nesse sentido, Santo Agostinho em Confissões descreve como é o longo percurso para encontrar a recordação que procura:

\begin{abstract}
Chego agora aos campos e às vastas zonas da memória, em que repousam os tesouros das inumeráveis imagens de toda a espécie de coisas introduzidas pelas percepções; em que estão também depositados todos os produtos do nosso pensamento, obtidos através da ampliação, redução ou qualquer outra alteração das percepções dos sentidos, e tudo aquilo que nos foi poupado e posto à parte ou que o esquecimento ainda não absorveu e sepultou. Quando estou lá dentro, evoco todas as imagens que quero. Algumas apresentam-se no mesmo instante, outras fazem-se desejar por mais tempo, quase que são extraídas dos esconderijos mais secretos. Algumas precipitam-se em vagas, e enquanto procuro e desejo outras, dançam a minha frente com ar de quem diz: "Não somos nós por acaso?", e afasto-as com a mão do espírito da face da recordação, até que aquela que procuro rompe na névoa e avança do segredo para o meu olhar; outras surgem dóceis, em grupos ordenados, à medida que as procuro, as primeiras retiram-se perante as segundas e, retirando-se, vão recolocar-se onde estarão, prontas a vir de novo, quando eu quiser. Tudo isto acontece quando conto qualquer coisa de memória. (AGOSTINHO apud LE GOFF, 2006, p.440)
\end{abstract}

O narrador-personagem seleciona e filtra experiências que considera como sendo mais significativas, de forma ainda desordenada, imaginando "as quatro portas abertas" de sua mente, "suspensas numa claridade exata", prontas para exploração (METZ, 1995, p.57). Diante dos fragmentos recolhidos, acredita estar pronto para registrar o que se tornaria "um trabalho sobre o sul", ou seja, poderia começar a escrever uma obra que falasse sobre sua alma e sua memória (METZ, 1995, p.57). Dentro de si vislumbra "clareza e de réstia e de bico de luz aceso. Parecia mesmo, ali sentado, poder tocar o pensamento e modular uma imagem sem auxílio de êxtase" (METZ, 1995, p.58). É a construção frente à inspiração, o escritor que elabora e trabalha arduamente seu texto a partir de uma formulação de uma imagem, não dependendo de um momento de transe absoluto, de um cataclismo emocional ou de uma transcrição divina para escrever. 
No entanto, o poeta-personagem-construtor sofre "a conhecida ansiedade, o ritmo do coração, a força desgovernada em tentar elucidar a todo o instante misturava a desgraça da razão na emoção, entorpecendo e velando o que estava para revelar-se. Aquilo vazio e parecendo não feito" (METZ, 1995, p.58). Em meio a tantas sensações, os "ombros [lhe] pesavam pela ordem simples da verdade que ali se dispusera de modo a ser intuída" (METZ, 1995, p.58). Essa inquietude e a constatação de tantas possibilidades ainda não realizadas (aquilo = papel/obra, vazio; não feito), somadas à grande responsabilidade que o narradorpersonagem se impôs (os ombros pesados, suportando o mundo, como diria Drummond), paralisam-no diante do pensamento a ser modulado. Contudo, ao mesmo tempo, representam a mola propulsora para a motivação da escrita.

O narrador-personagem vai além da recordação ao tentar desvelar informações do cérebro que não lhe são acessíveis: "uma asfixia, uma longa nuvem, vinda de algumas regiões do cérebro, enegrecia lembranças e apagava temas e engolia nexos, alguns que foram importantes, que foram mesmo irretorquíveis, nascidos de uma unidade de um destino. Agora estavam fora, estranhos, irreconhecíveis" (METZ, 1995, p.61). A percepção da primavera, por exemplo, ocorre em um nível que não comporta justaposições, já que a formação dessa memória foi modulada de forma lírica, significativa e única: "Gavinhas, trancelins, linho colhido. Vapores da terra perto das casas. Recolhendo ramos enegrecidos, a primavera veio brincar mais uma vez no ombro da aldeia” (METZ, 1995, p.7). Essa percepção se transforma em experiência e essa experiência se torna memória, que pode ser feita e desfeita, estar presente ou ser enegrecida e apagada. Porém, para o narrador-personagem, o terreno da memória é arenoso e fugidio: "Um fundo escorregadio sumia um muro inteiro deixando um pátio nu. Não havia mais lado nas coisas. Tetos, janelas, árvores imensas. A tentativa de dar forma ou de articular esquecimento e lembrança, e assim esboços de unidades, enfim foi me abandonando" (METZ, 1995, p.16). O alto grau de complexidade de sua mensagem se torna mais visível quando define, lá pelas tantas, o que entende por memória:

[...] a memória humana é uma das formas de superação do perecível e do momentâneo, e não apenas a capacidade de depositar e recordar, isto é, de tornar presente - trazendo-os do depósito onde é guardado o subconsciente e o que é semi-esquecido - idéias, impressões e sentimentos; ela é também uma determinada estrutura ativa e organizada da consciência humana, conhecimento. Pesadelos. Acréscimos. Rastilhos. É uma capacidade e uma estrutura histórica, porque é baseada não apenas no âmbito e no conteúdo do conhecimento que se modifica historicamente, mas também na faculdade racional-sensível do homem, que se desenvolve historicamente. (METZ, 1995, p.86) 
No entanto, assim que conceitua, fato raro no livro, volta urgentemente ao estilo inicial. Em uma profusão de palavras diz: "Precisei de uma lista de palavras-enredos que me colocassem novamente a imaginar: coachar, galochas, grinaldas. Pinguelas, cauda de cachorro, bruxarias, gato miando, pulga, sabonete. Pacotinhos, saquetes, girando na xícara. Conforto, confiança e confraria.” (METZ, 1995, p.86). A overdose gráfica que lhe acomete, cada vez que se aprofunda em seu interior, faz com que analise profundamente o valor de uma obra literária e o que é necessário para realizá-la. Antes de juntar as palavras, como dito anteriormente, há o nada: "Silêncio, bruma, vazio" (METZ, 1995, p.47). E mais: "Somos água e palavras, palavras que irão partir" (METZ, 1995, p.83). Antes de escrever, é necessário encontrar uma palavra, que irá contaminar a todas as outras: "uma palavra-pólen" (METZ, 1995, p.62), que irá fecundar. Só que a palavra por si só não basta, pois o que procura é um recontar de uma forma significativa. Para o narrador-personagem, a literatura não está nos nomes, nas classificações, nas anotações dispersas, na imagem concreta, mas na inovação, na originalidade da tradução entre o que se conhece e o que se quer escrever. Ao explorar as possibilidades do que poderia ser, em vez de se deter no que realmente é, pode ver além do imediato, produzir uma profusão de idéias, criar um personagem ímpar, "uma voz que nunca tivesse visto nada, que não buscava nada, desocupada desde a origem, mas que agora estava para sofrer as primeiras anotações, os primeiros moldes” (METZ, 1995, p.59).

\section{Gomercindo}

Uma manhã, ao despertar de sonhos inquietantes, Gregor Samsa deu por si na cama transformado num gigantesco inseto. (KAFKA, 1998, p.9)

Gomercindo é esse personagem. É muitos personagens em um só, é o "provérbio" (METZ, 1995, p.50), a peça da memória do narrador-personagem, o guardião das chaves ocultas da sua mente, que lhe traz algo novo, luminoso, que lhe oferece a revelação. Se o narrador procura uma grande obra, então, precisa de um grande personagem. Quando o encontra, vê nele proporções kafkanianas, distingue um Gregor Samsa ${ }^{6}$ (não casualmente no cinto de Gomercindo se pode ler as iniciais GS), ou um Dom Terceiro Azulado (METZ, 1995,

\footnotetext{
${ }^{6}$ Gabriel García Márquez descobriu que seria escritor ao ler Kafka e ver que era possível fazer com que um personagem se transformasse em um gigantesco inseto. Usando uma riqueza de imagens e uma forma imperturbável de ver as coisas, como se elas estivessem acontecendo naquele momento, escreveu, então, Cem anos de solidão.
} 
p.66), alusão a Don Segundo Sombra ${ }^{7}$ de Ricardo Güiraldes (1952). Gomercindo, nesse sentido, não apenas é um personagem representativo do regionalismo gauchesco latinoamericano, regido por um código de honra e de conduta particular, afeito à solidão pampeana, evocando um personagem lendário, mas também é o terceiro, o Dom Terceiro, que responde pela visão da alma do narrador-personagem:

Se somássemos todas as nossas fragilidades não seríamos reais ou tentaríamos nos fazer de outro material. Por isso somos para os pavilhões de isolamento, seres para o emplastro, o cataplasma, a febre [...] Quem pode ficar a sós com sua alma? Nós não a vemos, só os terceiros a enxergam. Mas os terceiros não enxergam as suas e nós somos os terceiros dos terceiros que não sabem como são, como nós eles também dependem de nosso ângulo, do nosso juízo. (METZ, 1995, p.33)

Quando Gomercindo fala, assume idéias e tendências do narrador-personagem: "Dizia coisas minhas nas dele, deslavadamente se apropriando de tudo, num furto profuso, elétrico, contagiado" (METZ, 1995, p.74). Gomercindo funciona, então, como um alter ego: "o que não existe, diz do que existe" (METZ, 1995, p.156), um personagem pertencente ao universo da memória do narrador-personagem, um ser multifacetado, que juntou os fragmentos $e$ retalhos, os reciclos e rejuntes (METZ, 1995, p.43-4), que uniu o fio narrativo. De acordo com Aristóteles (apud ABBAGNANO, 1999, p.657), "quem recorda deduz que já escutou ou percebeu aquilo de que se lembra; isso é uma espécie de busca”, que o narrador-personagem realiza em relação a Gomercindo exatamente no momento em que procura relacionar sua fisionomia ao grupo de pessoas conhecidas:

\footnotetext{
${ }^{7}$ Assim como Gomercindo, Don Segundo mostra ser um homem sábio, conhecedor do campo e da vida. Don Segundo aconselha e adota como afilhado Fabio, que vai garantir a preservação de sua memória no pampa, lugar onde "las impresiones son rápidas, espasmódicas para luego borrarse en la amplitud del ambiente, sin dejar huella" (GÜIRALDES, 1952, p.52). Sobre as marcas deixadas por Don Segundo Fabio testemunha: "Cinco años habían pasado sin que nos separáramos ni un solo día, durante nuestra penosa vida de reseros. Cinco años de esos hacen de un chico un gaucho, cuando se ha tenido la suerte de vivirlos al lado de un hombre como el que yo llamaba mi padrino. Él fue quien me guió pacientemente hacia todos los conocimientos de hombre de pampa. Él me enseñó los saberes del resero, las artimañas del domador, el manejo del lazo y las boleadoras, la difícil ciencia de formar un buen caballo para el aparte y las pechadas, el entablar una tropilla y hacerla parar a mano en el campo, hasta poder agarrar los animales donde y como quisiera. Viéndolo me hice listo para la preparación de lonjas y tientos con los que luego hacía mis bozales, riendas, cinchones, encimeras, así como para injerir lazos y colocar argollas y presillas. [...]También por él supe de la vida, la resistencia y la entereza en la lucha, el fatalismo en aceptar sin rezongos lo sucedido, la fuerza moral ante las aventuras sentimentales, la desconfianza para con las mujeres y la bebida, la prudencia entre los forasteros, la fe en los amigos. Y hasta para divertirme tuve en él a un maestro, pues no de otra parte me vinieron mis floreos en la guitarra y mis mudanzas en el zapateo. De su memoria saqué estilos, versadas y bailes de dos, e imitándolo llegué a poder escobillar un gato o un triunfo y a bailar una huella o un prado" (GÜIRALDES, 1952, p.65). Na visão de Fabio, Don Segundo era "por sobre todo y contra todo, Don Segundo quería su libertad. Era un espíritu anárquico y solitario, a quien la sociedad continuada de los hombres concluía por infligir un invariable cansancio" (GÜIRALDES, 1952, p.66).
} 
Buscava reconhecer aquele rosto em alguém da minha família. Buscava reconhecê-los entre os das famílias que vi. Mas era uma fisionomia árida para a lembrança, composta mais de meio século antes de eu nascer, e ainda com vagas zonas de juventude onde sua idade não havia penetrado por inteiro. (METZ, 1995, p.73)

Gomercindo mostra a experiência de sua instrução filtrada pela leitura de páginas escritas e pela cultura oral. Quando se tornou contrabandista, transitou pela fronteira e leu livros em espanhol. O filtro de narração de Gomercindo na narrativa manifesta, assim, um processo de assimilação de uma cultura clássica/erudita de uma série de relatos e textos que dará um caráter único para suas afirmações. Ao mesmo tempo, seu discurso remonta uma antiga tradição oral, de antigos conhecimentos sobre a terra, sobre as pessoas, que facilitaram para que se tornasse a figura indispensável na organização das tropas ilícitas de vaqueanos e para que pudesse dar conselhos ao narrador-personagem. Sendo um homem que sabe aconselhar, transmite um saber, ou como diz Benjamin, em $O$ narrador. Considerações sobre a obra de Nikolai Leskov (1996, p.200), sugere "a continuação de uma história que está sendo narrada". Observador e pertencente a este mundo em mudança, Gomercindo apresenta a relação do ser humano com o seu tempo passado.

\section{0 pacto}

Cuido que já 'stamos no país fantástico de encantos e sonhos. Avante, bom guia! Transpõe estes páramos vazios, tristonhos. Como umas trás outras nos fogem as árvores, recurvas, ligeiras! E os serros baixando-se! E os roncos e os sibilos das rotas pedreiras, que vão a arquejar! Que palram as águas? que diz toda a harmônica loquaz natureza? Serão ternas mágoas, queixumes, ou cânticos? é gozo? é tristeza? de dias celestes celestes memórias? amor? esperança? recordos confusos de gostos pretéritos? vão eco? ou lembrança de lenda a passar? (GOETHE, 1919, p.357).

Em Assim na Terra (1995) “os pactos estão circulando” (METZ, 1995, p.28). A narrativa de Assim na Terra (1995) imbrica a possibilidade de realização tanto do pacto demoníaco (para se obter em troca um grande texto literário), quanto do pacto de amizade e honra entre Gomercindo e o narrador-personagem. Associando leituras e autores, tanto no que se refere ao pacto com o demônio quanto ao pacto com Gomercindo, a busca do narradorpersonagem, em primeiro lugar, volta-se para o conhecimento, do mundo e de sua alma. Antes de tudo, o narrador-personagem preconiza: “Quem pode ficar a sós com sua alma?”, acaso o “olhar evita um pacto?” (METZ, 1995, p.33).

Ao longo da narrativa o narrador-personagem assume várias vozes de escritores que leu: Aristóteles, Eliot, Hemingway, Platão, Güiraldes, Borges, Sábato, Valéry, Mallarmé, 
entre outros, mas é quando ressoa Goethe e Guimarães Rosa que se aproxima mais de um suposto pacto demoníaco: "Minha voz ecoava e era Goethe e era, agora, um outro autor também [...]” (METZ, 1995, p.64). Ao presenciar a cena de um homem que está vendendo a alma em uma encruzilhada, o narrador-personagem se questiona sobre qual seria o benefício, ou melhor, o que pediria em troca se realmente fizesse um pacto, e assim como Riobaldo diz “eu quase que nada não sei” (GUIMARÃES ROSA, 1988, p.8), relembrando Sócrates na máxima "só sei que nada sei”, o narrador-personagem conclui: "O que eu quero ainda não sei, não sei de nada".

\begin{abstract}
Chegaria o vento com os seres dentro dele que do rito se avistam e desceriam uma caderneta cheia de notas perfeitas sobre alguns instantes que provavelmente estão a minha frente? $\mathrm{Eu}$ guardaria no bolso de trás e estaria igualmente incompleto, envolvido num leque de angústias que afloram depois de cada parágrafo? Mas se conseguisse escrever, na intercessão, uma parábola missioneira genuína e geral como melodia que toca o boi e o amor com simultânea embriaguez? Poderia enterrar minhas mãos na terra ferroante, mas o que quero em troca? O que eu quero ainda não sei, não sei de nada. (METZ, 1995, p.26)
\end{abstract}

Não há resolução do pacto, muito menos sua confirmação absoluta, mas ao deparar-se com o demônio, diz-lhe "do alto e do centro, do lugar onde estava, que ele poderia nomear a condição de possuídos pela vocação, pelo destino, por uma poderosa latência na própria existência" (METZ, 1995, p.65). Da mesma forma como para Riobaldo, o demônio não se anuncia: "Mas nada ouvi em resposta. Estaria me faltando uma encruzilhada? O avesso da fé? Olhei o tampo da escrivaninha lá embaixo. Uma pequena vela estava queimando em silêncio sobre a madeira polida" (METZ, 1995, p.65). Ainda assim o "Demônio é quem preside a toda a criação, a toda produção e tem a chave de uma obra que ainda não existe em parte alguma" (METZ, 1995, p.65).

Quando os dois personagens partem em viagem, o pacto se cumpre. Então, o narradorpersonagem não somente se mostra preparado para reinventar a história, mas também para o fim do personagem:

Tudo passa, tudo cala, tudo é vento sobre a noite. Ali estava um homem e o tempo deste homem, e o que é tempo nele no símbolo é levado, sua intimidade, sua lágrima na minha, como se prosseguisse uma imagem, uma estrofe, uma impermeável perseguição. Tudo passa, tudo é vento sobre a noite. O tempo e o homem se excluem na mesma luz. (METZ, 1995, p.147)

\title{
6. A obra e o leitor
}

[...] el libro es una extensión de la memoria y de la imaginación. (BORGES, 2006, p.9) 
Nessa torturante expedição interior em que o narrador-personagem mergulha, ao leitor que se angustia há um alento: "Não é um problema da obra que jaz sem angústia, mas do autor e do leitor, que permanecem fustigados. Quem construiu e quem habita devem seguir um projeto que a obra conclusa anuncia. O que está feito nos acompanha e nos rege" (METZ, 1995, p.68). A obra está em algum lugar procurando um autor e um leitor, afinal, como disse Borges (2006), um livro só toma vida quando é aberto, antes disso é mero conjunto de papel e couro. Cada leitor acrescenta algo novo e enriquece a obra, "los libros están cargados de pasado" (BORGES, 2006, p.22).

Em Assim na Terra (1995) o "autor e o leitor [estão] mortos, apenas a obra dialogando no abstrato parador, onde vive nossa confraria sem atas, num rancho, as portas sempre abertas ao sinal da vida para a folha" (METZ, 1995, p.75). Nessa interação leitor-obra, o narradorpersonagem se dá conta de que as palavras, às vezes, não abarcam tudo o que gostaria de dizer, mas sabe que, depois da publicação, a obra está aberta para a interpretação do leitor: "as grandes obras são vampiros sedentos que secam o vigor de vários homens ao longo de épocas, sugando-nos para se perpetuarem, se alimentam das reinterpretações, aplacando e apagando quem toma contato com seus âmagos encantados" (METZ, 1995, p.119). Contudo, mesmo depois dessa reflexão, o narrador-personagem ainda duvida:

Deixei de recordar. Tentei ficar mais presente. Logo estava de posse de uma única culpa, que andara foragida. [...] Depois havia aquela sensação de coisa não feita, faltando. De desperdício, de inconclusão, uma inquietação quase alheia, que se aloja e gira. [...] Cadernos de anotações: só para outros, uns instantes de outros, que os revisam e somem ou recopiam e vão. (METZ, 1995, p.83).

Logo, porém, livra-se da posse dessa culpa quando afirma que a "palavra é a nossa única saída, água de quase tudo, do cisne ao álibi” (METZ, 1995, p.83). A palavra é o cisne que representa a beleza e ao mesmo tempo é o álibi que apresenta a justificativa. Por tudo isso, um livro precisa ser escrito logo - o tempo passa, as coisas mudam, perdem-se, transformam-se -, como bem mostra a fala de Gomercindo:

Escreva. Escreva logo. O tempo mudou. [...] Eu vivo uma obra. Uma obra precisa anos para se escandir, chegar no seu tempo, eu estou chegando nele. Mas não sou autor nem leitor e sou um testemunho. Tenho uma maneira de ver as coisas, uma forma, uma construção. Eu utilizo as coisas para preservá-las. (METZ, 1995, p.67)

“A obra é a morte do autor e é a sua vida, pois é a saudade que nos faz registrar" (METZ, 1995, p.76), ou seja, a obra em si por mais que fale da memória, da vida do autor 
(saudade), na intenção de imortalizar suas idéias (registro), ultrapassa a idéia original do autor $^{8}$. Assim na Terra (1995) questiona o material usado em uma grande obra literária, fala sobre a posição narrativa, a criação do personagem, a construção do texto (a terra que será fecundada), sem contar que é um livro sobre o conceito memória e de memória, já que utiliza os fatos e impressões da trajetória de um personagem. É um momento que já passou, mas que retorna cada vez que o leitor abre o livro e estabelece um diálogo. A memória nos diz quem somos. Nas palavras de Norberto Bobbio (1997, p.30), autor também reverenciado por Iván Izquierdo: "somos aquilo que pensamos, amamos, realizamos. [...] somos aquilo que lembramos. Além dos afetos que alimentamos, a nossa riqueza são os pensamentos que pensamos, as ações que cumprimos, as lembranças que conservamos e não deixamos apagar e das quais somos o único guardião."

\section{Referências}

ABBAGNANO, Nicola. Dicionário de Filosofia. São Paulo: Martins Fontes, 1999.

BENJAMIN, Walter. O narrador. Considerações sobre a obra de Nikolai Leskov. In: Magia e técnica, arte e política: ensaios sobre literatura e história da cultura. 7. ed. São Paulo: Brasiliense, 1994. (Obras escolhidas. v. 1). Trad.: de Sérgio Paulo Rouanet.

BOBBIO, Norberto. O tempo de memória: de senectude e outros escritos autobiográficos. Rio de Janeiro: Campus, 1997.

BORGES, Jorge Luis. Borges oral. Madrid: Alianza, 2006. Obra poética, 2. Madrid: Alianza, 1998.

CORTÁZAR, Julio. Algunos aspectos del cuento. In: Obra Crítica/2. ALAZRZKI, Jaime. (ed.). 1. ed. Buenos Aires: Suma de Letras Argentina, 2004.

ELIOT, T.S. Os quatro quartetos. Tradução de Ivan Junqueira. Introdução de Antônio Houaiss. Rio de Janeiro: Civilização Brasileira, 1967.

GOETHE, Johann Wolfgang von. Fausto. Lisboa: Livraria Clássica Editora de A. M. Teixeira, 1919.

GUIMARÃES ROSA, João. Grande sertão: veredas. Rio de Janeiro: Nova Fronteira, 1986.

GÜIRALDES, Ricardo. Don Segundo Sombra. Buenos Aires: Losada, 1952.

\footnotetext{
${ }^{8}$ Segundo Borges (2006, p.15): “[...] un libro tiene que ir más allá de la intención de su autor. La intención del autor es una pobre cosa humana, falible, pero en el libro tiene que haber más". Na realidade, "un libro se lee para la memoria" (BORGES, 2006, p.22).
} 
IZQUIERDO, Iván. Questões sobre memória. São Leopoldo: Unisinos, 2004.

KAFKA, Franz. A metamorfose. Rio de Janeiro: Ediouro, 1998. (Biblioteca de Babel)

KENNER, Hugh. The invisible poet T.S. Eliot. Londres: University Paperbacks, 1974.

LE GOFF, Jacques. História e memória. Tradução de Bernardo Leitão et al. 5. ed. Campinas, São Paulo: Editora da UNICAMP, 2003.

MÁRQUEZ, Gabriel García; APULEYO MENDOZA, Plinio. El olor de la guayaba. Conversaciones con Plinio Apuleyo Mendoza. Buenos Aires: Sudamericana, 1982.

METZ, Luiz Sérgio. Assim na Terra. Porto Alegre: Artes \& Ofícios, 1995. 